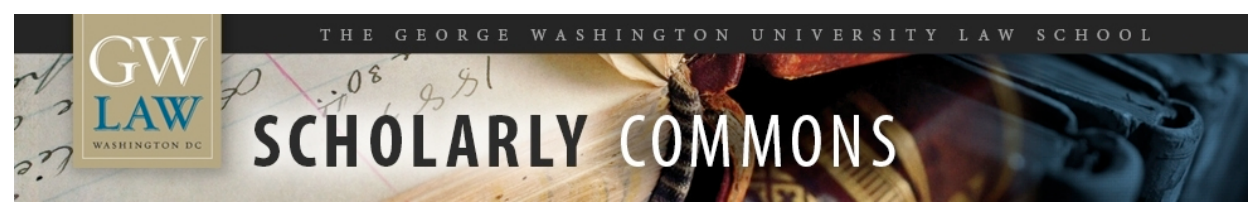

\title{
A Modest Proposal to Enhance Civil/Military Integration: Rethinking the Renegotiation Regime as a Regulatory Mechanism to Decriminalize Cost, Pricing, and Profit Policy
}

William E. Kovacic

George Washington University Law School, wkovacic@law.gwu.edu

Steven L. Schooner

George Washington University Law School, sschooner@law.gwu.edu

Follow this and additional works at: https://scholarship.law.gwu.edu/faculty_publications

Part of the Government Contracts Commons

\section{Recommended Citation}

Paper presented at the 1999 Defense Systems Management College (DSMC) Acquisition Research Symposium, June 21-23, 1999

This Conference Proceeding is brought to you for free and open access by the Faculty Scholarship at Scholarly Commons. It has been accepted for inclusion in GW Law Faculty Publications \& Other Works by an authorized administrator of Scholarly Commons. For more information, please contact spagel@law.gwu.edu. 


\section{A Modest Proposal to Enhance Civil/Military Integration: Rethinking the Renegotiation Regime as a Regulatory Mechanism to Decriminalize Cost, Pricing, and Profit Policy}

William E. Kovacic, Visiting Professor of Law, George Washington University Law School Steven L. Schooner, Associate Professor of Government Contracts Law, George Washington University Law School

\begin{abstract}
For better or worse, neither Congress, the procuring agencies, the media, nor the public will condone, conceptually, contractors reaping excessive profits for government work. As a result, our current procurement system employs an unduly complex, burdensome, and risk-laden system that ineffectively endeavors to limit excessive profits. This statutory and regulatory regime erects significant barriers to civil/military integration.
\end{abstract}

Progressing from our conclusion that the avoidance of excessive profits is an immutable characteristic of government procurement, we acknowledge persistent criticism of, and the renewed effort to avoid, cost-based contracting. This inevitably leads us to problems associated with the pricing practices that pervade fixed-price contracting. We then examine certain policy implications associated with the Truth In Negotiations Act (TINA), the existing audit regime, and the use of criminal and civil anti-fraud measures to scrutinize deviations from these complex cost, pricing, and profit policies and controls.

Both the Defense Department and private industry aggressively criticize the current state of contract pricing, cost reimbursement contracting regulation, and contract profit policy. Detractors assert that the statutory and regulatory regime poses significant impediments to civil/military integration
We then re-visit the Renegotiation Act, extinct for more than twenty years, and find it less troubling than the existing quagmire. We analogize to recent experience in the public utilities industry, which increasingly employs a sharing mechanism as an explicit, transparent means for addressing "excessive" profits. Finally, we make a modest proposal to simplify and decriminalize Federal procurement pricing and profit policy that draws from the historical renegotiation experience.

We suggest that a transparent renegotiation regime could be one less burdensome or complex element of a regulatory scheme that presents suppliers with a menu of regulatory options. Such a regulatory scheme would allow contractors to select the approach that best corresponds to their own assessment of which contractual rules will minimize their costs. We conclude that such a regime could permit the Government to share, directly or indirectly, in these increased efficiencies and savings.

\section{Introduction}

(CMI). ${ }^{\mathrm{i}}$ Critics assert that intrusive,

i DoD recently ranked numerous cost drivers, originally identify by a Coopers \& Lybrand/TASC study, in terms of their priority to CMI. Category 1 barriers (the highest priority) included the Truth in Negotiations Act, Cost Accounting Standards, Contract Cost Principles, and Contract 
burdensome, government-unique requirements provide barriers to entry by commercial firms.

While debate continues regarding the true impact of these barriers, most participants and observers agree that impediments derive from the cost and complexities that burden government-unique requirements associated with: (1) the disclosure of cost or pricing information pursuant to the Truth In Negotiations Act (TINA), ${ }^{\text {ii }}$ (2) accounting allocation rules primarily associated with the Cost Accounting Standards (CAS), ${ }^{\text {iii }}$ and (3) the allowability of certain incurred costs, addressed in the regulatory cost principles. ${ }^{\text {iv }}$ Superimposed upon this framework is a legitimate concern regarding the use of criminal and civil anti-fraud measures, primarily through the 1986 amendments to the False Claims Act (FCA), ${ }^{\mathrm{v}}$ to scrutinize deviations from these complex cost, pricing, and profit policies and controls.

Viewed from afar, the existing maze of statutes and regulations that affect contract pricing seem unduly complex, burdensome, and, in the case of potential sanctions, risky,

Administration and Reporting. See, e.g., DoD Ranks Cost Drivers' Impact on Civil-Military Integration, 40 GOV'T CONTRACTOR II 550 (December 9, 1998).

iii See generally, Pub. L. No. 91-379, 50 U.S.C. app. § 2168; 41 U.S.C. § 422; Federal Acquisition Regulation (FAR) Appendix B, 48 C.F.R. Part 9904.

iv Federal Acquisition Regulation (FAR) Part 31, 48 C.F.R. Part 31.

v $\quad 31$ U.S.C. $\$ \S 3729,3730 ; 18$ U.S.C. $\$$ 287. given their intended purpose. Arguably, these various mechanisms serve merely to ensure that contractors do not make "too much" profit on government contracts. There must be a better way.

For the purposes of this paper, we do not attempt to distinguish "excessive" profits from those deemed "exploitative." The adjectives are neither meaningful nor relevant. As discussed below, Congress has repeatedly demonstrated its ability to set broad, sweeping, seemingly arbitrary, percentage-based limits on contractor profits. In this paper, we do not seek to add to such an effort.

Nor do we advocate for profit controls generally. Rather, we begin from the assumption that the community - whether Congress, the procuring agencies, the media, or the public - will not tolerate, conceptually, contractors reaping excessive profits for government work. Faced with that reality, we propose a streamlined, equitable system to effectuate this policy.

In this brief paper, we assert that the Government, for better or worse, is incapable of tolerating excessive contractor profits. We suggest that our current unduly complex, burdensome, and risk-laden system ineffectively endeavors to limit excessive profits. We re-visit the Renegotiation Act, extinct for more than twenty years, and find it less troubling than the existing quagmire. Finally, we make a modest proposal to simplify and decriminalize pricing and profit policy and practice that draws from the renegotiation experience.

\section{Government Fixation With Avoiding Excessive Profit, Or Having Their Cake and Eating It Too}

We begin by suggesting that the avoidance of contractors obtaining excessive 
profits is an immutable characteristic of government procurement. ${ }^{\mathrm{vi}}$ Twentieth centrury American history is replete will failed attempts to curb wartime contractor profits. ${ }^{\text {vii }}$ Statutory profit ceilings date back to the passage of the Vinson-Trammel Act of $1934^{\text {viii }}$ and the Merchant Marine Act of 1936. ${ }^{\text {ix }}$ In 1942, the Supreme Court bemoaned the problem but left no doubt that Congress, not the courts, possessed the power and responsibility to address the concern. ${ }^{\mathrm{X}}$

vi See, generally, Hult Lawrence Wilson, Renegotiation: Pro and Con, 10 LAW \& CONTEMP. PROBS. 376, 377-78 (1944), asserting that one point of agreement is "the immorality of excessive profits."

vii See generally, H. Struve Hensel \& Richard G. McClung, Profit Limitation Controls Prior to the Present War, 10 LAW \& CONTEMP. PROBS. 187 (1944); Glen A. Lloyd, Pricing in War Contracts, 10 LAW \& CONTEMP. PROBS. 235 (1944).

viii

48 Stat. 505 (March 27, 1934) (capping Navy contract profits at ten percent). Later iterations of the Vinson-Trammel Act altered coverage and profit rates. 49 Stat. 1926 (June 25, 1936); 53 Stat. 555, 560, 590 (April 3, 24, 25, 1939); 54 Stat. 676, 677 (June 28, 1940). See also W. John Kenney, Coverage and Exemptions, 10 LAW \& CONTEMP. PROBS. 262 (1944) (discussing these statutes and the Renegotiation Act).

ix $\quad 49$ Stat. 1985, 1998 (June 29, 1936) (limiting ship construction contract profit to ten percent).

x "The profits made in these ... contracts may justly arouse indignation. ... . But if the Executive is in need of additional laws to protect the nation against war profiteering, the Constitution has given to Congress, not to this Court, the power to make them[.]" United States v. Bethlehem
Prior to passage of the first profit renegotiation statute, Congress considered statutory profit limitations (at varying levels), excess profit taxes, renegotiation, and other options. In a representative expression of outrage at "parasites" engaged in "nefarious practices," Representative J.W. Ditter of Pennsylvania, explained:

The problem to which I refer . . . is the elimination of exorbitant or excessive profits on war contracts. . . $[\mathrm{N}]$ othing more than a reasonable return on capital and on ability, bearing in mind the degree of risk involved in both, should accrue to any man .... as a result of the national peril. The trite phrase -take the profits out of war -- should mean just what it says. . . [W] e have evidence at hand of the existence of what has been very properly termed "blood money[.]"xi

This sentiment is neither confined to wartime exigency, nor is it consistent with capitalistic notions of the role of profit in markets.

When DoD introduced its "weighted guidelines," now more than thirty years ago, it touted profit as the engine that drives

Steel Corp., 315 U.S. 289, 308-309 (1942).

See generally, James F. Nagle, A HiSTORY OF GOVERNMENT CONTRACTING, 350-353, 439442 (1992).

xi Excerpts from Debate in House of Representatives on Adoption of Conference Report on H.R. 6868, $77^{\text {th }}$ Cong., Cong. Rec. of April 21, 1942, 3695-3712, reprinted in COMMITTEE ON WAYS AND MEANS, RENEGOTIATION OF WAR CONTRACTS, LAW, DEBATES, AND OTHER LEGISLATIVE MATERIALS, 100-101 (Barron K. Grier, Compilation, 1943). 
successful contractual performance. DoD articulated that its policy was "to utilize profit to stimulate efficient contract performance. Profit . . . is the basic motive of business enterprise. . Negotiation of very low profits .... does not provide the motivation to accomplish such performance. . . [L]ow average profit rates on defense contracts overall are detrimental to the public interest."xii Professor Nash, at the time, suggested that the new policy intended not only to use profit to better motivate performance, but also to establish profit rates at levels more fair to contractors. ${ }^{\text {xii }}$ These

xii $\quad$ ASPR 3-808.I(a) (1963).

xiii Ralph C. Nash, Jr., Pricing Policies in Government Contracts, 29 LAW \& CONTEMP. PROBS. 361, 372-373 (1964). Professor Nash also detailed the inexorable reduction in profit rates on defense contracts, charting a steady decline in profit rates from 6.36 percent in 1956 to a startling 2.94 percent in 1963 . Id. at 370 , note 30 , extracting data from the Annual Reports to Congress submitted by the Renegotiation Board. See also RALPH C. NASH \& JOHn Cibinic, JR., PROFIT Planning (Geo. Wash. Univ. undated course book, circa 1964-65), summarizing the net profits of the twenty largest DoD contractors (accounting for $46.5 \%$ of total DoD procurement) in 1962. The highest net profits reported in 1962, were General Motors, with a $10 \%$ net profit on sales and General Dynamics, with a $31 \%$ net profit based on invested capital. At the same time, it was observed that, under the new rules, "there is an insufficient profit ... to cover product development costs, contingencies implicit in a 'proprietary product' business, and other 'unallowable' costs, if at the same time a fair return to the contractor's stockholders is to be provided. . . . [I]n practice anything more than a modest profit, ranging somewhere in the neighborhood of plus or minus ten percent on fixed-price jobs, is unacceptable. .." Walter same principles are embodied today in the Federal Acquisition Regulation (FAR). ${ }^{\text {xiv }}$ This policy, however, is articulated in the same section describing the long-standing, but seemingly arbitrary, profit limitations which Congress has set for various categories of contracts. ${ }^{\mathrm{xv}}$

A chasm exists between the stated policy and current practice, and the Government cannot (or at least should not be able to) have it both ways. ${ }^{\text {xvi }}$ In much of its current

F. Pettit, The Defective Pricing Law and Implementing Regulations - A Year and a Half Later, 29 LAW \& CONTEMP. PROBS. 552, 561-62 (1964).

xiv FAR 15.404-4(a)(2) explains that: "It is in the Government's interest to offer contractors opportunities for financial rewards sufficient to stimulate efficient contract performance, attract the best capabilities of qualified large and small business concerns to Government contracts, and maintain a viable industrial base." FAR 15.404-4(a) warns: "Both the Government and contractors should be concerned with profit as a motivator of efficient and effective contract performance. Negotiations aimed merely at reducing prices by reducing profit, without proper recognition of the function of profit, are not in the Government's interest."

xv See FAR 15.404-4(c)(4)(i), which prohibits contracting officers from negotiating prices or fees exceeding the statutory limitations in 10 U.S.C. $\$ 2306$ and 41 U.S.C. $\S 254$, of 15 percent for experimental, developmental, or research work performed under cost-plus-fixed-fee (CPFF) contracts; 6 percent for architect-engineer services; and 10 percent for other CPFF contracts.

xvi See e.g., Joshua I, Schwartz, Assembling Winstar: Triumph of the Ideal of Congruence in Government Contracts Law?, 
rhetoric, the Government implies that it is willing to buy commercial items and act as any other party to a commercial transaction. ${ }^{\text {xvii }}$ Yet, only the naive could believe that Congress or the public will be any more tolerant of profits deemed excessive simply because they were reaped by "commercial" firms or derived from "commercial item" purchases.

\section{Complexity and Criminalization: Potential Barriers To Entry For Commercial Firms}

26 PUB. CONT. L. J. 481 (1997); Joshua I, Schwartz, Liability for Sovereign Acts: Congruence and Exceptionalism in Government Contracts Law, 64 GEO. WASH. L. REV. 633, 674-76 (1996) (contrasting a "congruence principle" in government contract law -- that in its contractual relations the government's rights and duties resemble those of private parties -- with an "exceptionalistic" principle -- that the government can, for example, annul agreements based upon federal police, or some other paramount, power).

xvii See generally, Steven Kelman, Buying Commercial: An Introduction and

Framework, 27 PUB. CONT. L. J. 249 (1998);

William P. McNally, Will Commercial Specifications Meet Our Future Air Power Needs?, ACQUISITION REVIEW QUARTERLY 297 (Summer 1998); Michael Heberling, J. Ronald McDonald, R. Michael Nanzer, Eric Rebentisch \& Kimberly Sterling, Using Commercial Suppliers - Barriers and Opportunities, PROGRAM MANAGER 48 (July/August 1998); Michael H. Anderson \& Eric Rebentisch, Commercial Practices-Dilemma or Opportunity?, PROGRAM MANAGER 16 (March/April 1998); Michael E. Heberling \& Mary E. Kinsella, Remaining Issues in Adopting Commercial Practices in Defense Acquisition, 38 CONT. MGMT. 13 (February 1998).
Whether due to an irrational obsession with avoidance of excess profits or a wellintentioned effort to ensure that the Government obtains the best value for its procurement dollar, the result has been the same. Our current procurement system imposes significant barriers to entry to commercial firms. Although these barriers may differ based upon the type of contractual vehicle employed -- for example the use of cost-based versus fixed-price contracts -- the symptoms are similar: complex, resource intensive compliance requirements with corresponding risks.

\section{Cost-Based Contracting; Neither Poison Nor Panacea}

Cost reimbursement contracting arguably reduces the risks contractors must assume when uncertainties in contract performance do not permit costs to be estimated with sufficient accuracy to use any type of fixed-price contract. These contractual vehicles obligate the Government to reimburse contractors for their allowable incurred costs, typically within a stipulated ceiling. ${ }^{\text {xviii }}$ Recent acquisition reform effort and energy, however, have focused upon reducing the use of cost-based contracting. ${ }^{\text {xix }}$

Criticisms of cost-based pricing are neither new nor novel. As early as 1943, the Truman Committee concluded that: "Experience has shown 'cost-plus' contracts to be worse than worthless in the effort to prevent excessive costs. They strongly tend to increase costs instead of the reverse." ${ }^{\text {,x }}$

\footnotetext{
xviii FAR 16.301-1, 16.301-2.

xix See e.g., John Cibinic, "Cost-Based" Contracting: On the Way Out?, 12 NASH \& CiBNIC REP. II 58 (November 1998).

xx $\quad$ Senate Rep. No. 10, Part 5, p.2, $78^{\text {th }}$ Cong., $1^{\text {st }}$ Sess., March 30, 1943. For
} 
Further, the infrastructure required to administer and comply with the regulatory requirements associated with cost-based contracting absorb a significant portion of the Government's investment in these contracts.

Nonetheless, it appears unlikely that the end of cost-based contracting is near. Elimination of this contracting option seems impracticable absent a sufficient alternative to insulate contractors from assuming excessive financial risk on large, development projects that, for example, seek to expand the state of the art. Further, wholesale change "will require a cultural change of immense proportions and a major cleanup of the FAR" regulatory scheme. ${ }^{\mathrm{xxi}}$ Nonetheless, it appears reasonable to expect the pendulum to continue to swing towards a preference for fixed-price vehicles. In either event, energy must be devoted to reducing the administrative and compliance burdens associated with either type of pricing mechanism.

\section{Fixed-Price Contracts in Theory and Practice}

Fixed-price contracts (FFP) commit the supplier to perform the contract at a specific price, regardless of actual performance costs. The FAR describes the incentive features of FFP contracts as placing:upon the contractor the maximum risk and full responsibility for all costs and resulting profit or loss. It provides maximum incentive for the contractor to control costs and perform effectively and imposes a minimum

background on the Truman Committee, see James F. Nagle, A History OF GOVERnMENT CONTRACTING, 423-25, 440-441 (1992).

xxi John Cibinic, "Cost-Based" Contracting: On the Way Out?, 12 NASH \& CIBNIC REP. II 58 at 174 (November 1998). administrative burden upon the contracting parties. ${ }^{\text {xxii }}$

The contractor thus absorbs all overruns and, conversely, retains all amounts by which actual performance costs underrun the contract price.

FFP contracts maximize incentives to control costs only if the contracting parties believe that renegotiation of the contract price is allowed only when (1) renegotiation is contemplated by the express terms of the original agreement and takes place pursuant to a mechanism specified in the agreement; or (2) contingencies during performance satisfy the strict requirements of contract law doctrines governing impossibility and unforseeability. ${ }^{\text {xiii }}$

Efforts to renegotiate terms outside these circumstances can weaken incentives to comply with the original contract terms in any one procurement episode; diminish the willingness of firms to contract with entities that have a reputation for attempting to reopen the original terms; or induce the parties to take costly precautions to account for the possibility that renegotiation will occur.

\section{The Truth In Negotiations Act: A Microcosm Reflecting The Larger Problem}

If the current compliance regime derives from the Government's efforts to avoid paying excess profits, TINA could not be more inefficient. If the Government truly desires to procure based upon best value, the information obtained during the negotiation
xxii FAR 16.202-1.
xxii $\quad$ See generally, Steven L. Schooner, Impossibility of Performance in Public Contracts: An Economic Analysis, 16 PUB. CONT. L. J. 229 (1986). 
process must be deemed irrelevant. Further, while only the successful offeror must certify its cost or pricing data, all offerors prepare the data as part of the proposal preparation process.

\section{The Content and Purpose of the Truth in Negotiations Act}

TINA stemmed from Congressional concerns that suppliers with sole-source contracts will negotiate excessive fixed prices with DOD because the lack of rivalry for the contracts at issue prevents market forces from exerting sufficient discipline over costs. TINA often applies to long-term production contracts for weapon systems, where DOD annually negotiates purchases with a sole supplier.

TINA compels contractors in negotiated procurements to reveal accurate, current, and complete "cost or pricing" data up to the time that the parties agree on the contract price. Cost or pricing data consists of all facts that "a prudent buyer or seller would reasonably expect to affect price negotiations significantly." "xxiv The contractor need not supply information that is "judgmental" but must reveal all facts on which its judgments rest. $^{\mathrm{xxv}}$ TINA does not apply to acquisitions

xxiv 10 U.S.C. $\$ 2306(h)(1) ; 41$ U.S.C. $\S$ 254b(i)(1); FAR 15.401. See also Jeffrey A. Lovitky, Understanding the Submission Requirement for Cost or Pricing Data, 21 NAT'L CONT. MGMT. J. 57 (Summer 1987); Jeffrey A. Lovitky, Cost or Pricing Data Defined: An Analysis of the Scope of Contractor Disclosure Requirements Pursuant to the Truth in Negotiations Act, 20 Nat'l Cont. Mgmt. J. 79 (Winter 1987).

xxv "Cost or pricing data are factual, not judgmental; and are verifiable. While they do not indicate the accuracy of the prospective contractor's judgment about estimated future below the simplified acquisition threshold ${ }^{\mathrm{xxvi}}$ or procurements where the contract price is based on (a) "adequate price competition," (b) established catalogue or market prices of commercial items sold in substantial quantitites to the general public, or (c) prices set by law or regulation. ${ }^{\text {xvii }}$

Contractors typically must certify that they have made the required disclosures. Price increases attributable to a failure to make the requisite disclosures constitute "defective pricing" and entitle DOD to recapture each dollar of overcharges caused by a nondisclosure. ${ }^{\text {xxviii }}$ Inaccurate certifications also can trigger or elicit formidable civil and criminal sanctions where the inaccurate certification contained a deliberate misrepresentation or displayed a reckless disregard for the truth. ${ }^{\text {xxix }}$ DOD uses extensive ex ante and ex post auditing tools to

costs or projections, they do include the data forming the basis for that judgment." FAR 15.401. See also, Jeffrey A. Lovitky, Understanding Causation and Determining the Price Adjustment in Defective Pricing Cases, 17 PuB. CONT. L. J. 407 (1988).

xxvi FAR 15.403-1(a). The simplified acquisition threshold, currently $\$ 100,000$, is established by Pub. L. No. 103-355. See also FAR Part 13's discussion of simplified acquisition procedures.

xxvii $\quad$ See generally, FAR 15.403-1.

xxviii See FAR 15.407-1, 15.408(b), (c); and the PRICE REDUCTION FOR DEFECTIVE COST OR PRICING clauses at FAR 52.21510 and 52.215-11.

xxix See generally, SEYFARTH, SHAW, FAIRWEATHER \& GERALDSON, THE GOVERNMENT CONTRACT COMPLIANCE HANDBOOK (2d ed. 1991 \& 1996 Supp.). 
determine whether the contractor has provided data subject to disclosure.

The likelihood that an audit can discover a TINA violation for any single contract is substantial, particularly for major weapons programs. In the period leading to an agreement on price, weapon suppliers daily generate large volumes of relevant information from internal sources and from external vendors. Exhaustive, expensive, post-negotiation "sweeps," intended to verify all conceivable data points, rarely prove foolproof. Items of cost or pricing data that are not supplied to DOD's negotiation team violate the disclosure requirement. The preparation and negotiation of pricing proposals provide many events that may constitute technical violations of the disclosure requirements.

\section{The Truth in Negotiations Act as a Renegotiation Mechanism}

A contractor's main incentive to commit itself to a fixed-price contract is the opportunity to keep amounts by which its costs underrun the contract price. Wellconceived price levels incorporate productivity improvement assumptions that allow DOD to benefit from productivity gains but still give the contractor strong incentives to achieve cost reductions that depress its actual costs below the fixed price. If the supplier greatly reduces its costs for any single contract, it will realize substantial profits for that contract.

DOD can react to these profits in two ways. The first is to treat a discrete period of high profits as unremarkable. High profits may result simply from superior performance, including efforts to improve productivity.

The second reaction is to regard a period of high profits as proof that the contractor manipulated the establishment of the fixed price. (This assumes, unfortunately and incorrectly, that generous contractor profits somehow must be inconsistent with the Government obtaining best value.) If it accepts the second hypothesis, DOD might dramatically adjust the fixed price downward in future contract periods or renegotiate $e x$ post to capture some of the returns from cost reduction in the initial contract period.

TINA induces contractors to reveal private information about anticipated costs. TINA's efficiency effects depend heavily on what the auditors regard as adequate information disclosures and how DOD responds to insufficient disclosures. One possible response is to treat high profits as proof that the contractor has failed to make mandated pre-contractual disclosures. High profits on individual contracts could trigger careful ex post audits of contractor data to determine whether the firm withheld information that, if disclosed during precontractual negotiations, would have led DOD to insist on a lower fixed price.

In practice, perceived contractor failures to make required disclosures usually result in efforts to recover the amount by which the contractor overstated its costs. Most annual production contracts for major weapon systems undergo extensive ex post audits to determine whether disclosures mandated by TINA were adequate. Since the early 1980s, the government has resorted increasingly to civil and criminal investigations premised on the view that nondisclosure was deliberate and done to defraud the government.

Price-ceiling regimes that enable regulators to recapture all or part of amounts by which the firm's earned rate of return exceeds a specific norm are not unique to government procurement. What distinguishes defense contracting are two features of the 
enforcement mechanism. First, DOD can threaten to commence a civil or criminal fraud inquiry to recapture excess returns. Second, the Civil False Claims Act empowers a contractor's employees to challenge apparent violations of the law. ${ }^{\mathrm{xx}}$

DOD audits unquestionably uncover some instances of willful contractor efforts to conceal data subject to disclosure duties. Yet DOD's use of TINA sometimes seems to support the hypothesis that the Government is renegotiating original contract terms and is seeking to obtain ex post a more favorable disposition of the surplus generated by contractor cost-cutting.

The certainty of probing, ex post analysis of actual cost experience could influence contractors in several ways. First, it could induce limit pricing by which firms forego efforts in any single negotiation to get the highest fixed price possible. Weapons programs often are repeat games consisting of a series of one-year contracts. ${ }^{\text {xxxi }}$ Firms may realize that high returns in one year may provoke ex post sanctions or lead DOD to impose severe price ceilings in future years.

xxx See William E. Kovacic, Whistleblower Bounty Lawsuits as Monitoring Devices in Government Contracting, 29 LOY. L.A. L. REV. 1799 (1996). Despite ongoing industry efforts to dilute the FCA provisions, it appears that any momentum in that direction may have dissipated. Melanie I. Dooley, DoD Drops Plan to Seek Statutory Changes to False Claims Act: Attorney General Offers to Draft Guidelines for Handling Fraud Cases, 71 FED. CONT. REP. 247 (February 22, 1999). xxxi See Keith J. Crocker \& Kenneth J. Reynolds, The Efficiency of Incomplete Contracts: An Empirical Analysis of Air Force Engine Procurement, 24 RAND J. ECON. 126 (1993).
Second, the prospect of renegotiation may diminish contractor efforts to cut costs in any one period, as cost reduction that boosts the return on the contract to levels unacceptable to DOD is likely to elicit unfavorable scrutiny. Firms may reduce efforts to achieve dramatic productivity gains or may be more inclined to tolerate expenditures that needlessly increase costs and reduce the overall return on the contract to levels DOD deems appropriate. Such caution would tend to impede bold efforts to cut costs and otherwise improve productivity.

Third, the possibility that the Government might seek criminal sanctions against the firm and individual employees can result in costly investments in administrative safeguards to ensure that even inadvertent nondisclosures of information do not occur. Suppliers also may delay the negotiation process to determine that strict compliance with TINA has been achieved before an agreement on price is reached.

Barring Congressional repeal of TINA -an unlikely occurrence -- what alternatives are available to permit the Government to insulate itself from excessive profit, while reducing the administrative burdens and risks of criminal sanctions that pose formidable barriers to entry into the Federal procurement marketplace? Perhaps history provides a useful analogy. 


\section{Revisiting The Renegotiation Act and Renegotiation Board.}

Commencing in the early 1940's and, in various iterations until its expiration in $1976,{ }^{\text {xxxii }}$ the statutory renegotiation scheme offered a global vehicle for addressing many of the concerns articulated above. Congress created renegotiation powers to ensure that the Government could fulfill its needs at fair prices during wartime. Basically, renegotiation permitted the Government to recover an amount determined to reflect a defense (or space) contractor's "excessive profits."xxxiii An independent Renegotiation Board administered the program from 1951 until 1979, when Congress ceased funding the Board. Congress permitted the Government's renegotiation authority to lapse in 1976.

xxxii "[R]epeated extensions of the act for short periods -- generally for approximately two years -- has been detrimental to the morale of the [Renegotiation] Board's personnel and to the proper functioning of the renegotiation process. ..." Andrew C. Mayer, Renegotiation, Congressional Research Service No. 77-136F, at i-ii (May 25, 1977).

xxxiii $\quad 50$ U.S.C. $§ 1213$, et seq. See generally, RALPH C. NASH, JR. \& JOHN Cibinic, JR. FEDERAL PROCUREMENT LAW, 1996-2026 (Vol. II, 3d ed. 1980). For more extensive history and analysis, see WALTER E. BARTON, RENEGOTIATION OF GOVERNMENT CONTRACTS (1952); HUDSON B. COX, RENEGOTIATION OF GOVERNMENT CONTRACTS UNDER THE 1951 AND 1948 RENEGOTIATION ACTS (1951); William L. Marbury \& Robert R. Bowie, Renegotiation and Procurement, 10 LAW \& CONTEMP. PROBS. 218 (1944); Jules Abels, The 1943 Revenue Bill's Renegotiation Proposals, 10 LAW \& CONTEMP. PROBS. 399 (1944).
History may recall that renegotiation served its purpose well, permitting significant recoveries for the public fisc. ${ }^{\text {xxiv }}$ Critics unsuccessfully challenged renegotiation as unconstitutional $^{\mathrm{xxxv}}$ or as abuse of sovereign power. $^{\text {xxxvi }}$

xxxiv From 1954 to 1958 , during the Korean War, annual determinations of excessive profits averaged $\$ 140$ million. ( $\$ 140 \mathrm{M}$ recovered in 1956 equates to approximately \$758M in 1998 dollars.) After the

Renegotiation Act was amended, permitting a five-year carry-forward, annual determinations of excessive profits averaged \$32.1 million until 1976. (\$32M recovered in 1975 equates to more than $\$ 90 \mathrm{M}$ in 1998 dollars.) RALPH C. NASH, JR. \& JOHN Cibinic, JR. FEDERAL PROCUREMENT LAW, 1998 (Vol. II, 3d ed. 1980). Current year dollars are calculated using NASA's Gross Domestic Product Deflator Inflation Calculator, available at <http://www.jsc.nasa.gov/bu2/inflate.html> (visited December 11, 1998).

xxxv Lichter v. United States, 334 U.S. 742 (1948) (constitutionality of Renegotiation Act upheld); Baltimore Contractors, Inc. v. Renegotiation Board, 383 F.2d 690 ( $4^{\text {th }}$ Cir. 1967) (Renegotiation Act of 1951 was "necessary and proper" and "within the constitutional power of Congress.). See also, Charles S. Collier, Constitutionality of Statutory Renegotiation, 10 LAW \& CONTEMP. PROBS. 353, 375 (1944) ("the most hopeful basis for attack [seems] to be, not the basic constitutionality of the statute, but the maladministration thereof in specific cases. . .”).

xxxvi Hult Lawrence Wilson, Renegotiation: Pro and Con, 10 LAW \& CONTEMP. PROBS. 376, 385-95 (1944). 
It is both interesting and significant that, in determining excessive profits, one of the primary factors was risk -- higher profits rates were permitted for firms whose business entailed comparatively higher risks. Favorable treatment in this regard typically was denied to contractors under cost reimbursement agreements. ${ }^{\text {xxxvii }}$

One attractive component of the renegotiation regime was that determinations and recoveries were not contract specific. ${ }^{\text {xxviii }}$ Rather, a composite fiscal year assessment of all of a firm's business provided the base for renegotiation. Losses on individual contracts could offset more profitable contracts. One less attractive component is that, like its present day successors, renegotiation procedures appear, at some level, intricate, complex, burdensome, and timeconsuming. ${ }^{\text {xxxix }}$

xxxvii See, e.g., Mason \& Hanger-Silas Mason Co. v. United States, 207 Ct. Cl. 106, 518 F.2d 1341 (1975) (profits in excess of two percent deemed excessive where contractor "incurred virtually no risk and invested very little capital of its own"); PageRiver-Curran v. United States, $216 \mathrm{Ct}$. Cl. 246, 574 F.2d 1063 (1978) (contractor's entitlement to profit on government furnished material (GFM) is lesser than on materials the contractor supplies).

xxxviii The original statute, passed in 1942, provided for renegotiation on a contract-bycontract basis. Sixth Supplemental National Defense Appropriation Act, $\S 403$, 56 Stat. 245. An amendment in October of 1942, however, converted renegotiation to a fiscal year basis. Revenue Act of 1942, § 801, 56 Stat. 982.

xxxix Carman G. Blough, Renegotiation Standards and Practices, 10 LAW \& CONTEMP. PROBS. 276 (1944); Paul B. Boyd, Administrative Machinery and Procedures for

\section{The DoD Repricing Rule: An Unintended} Analogy.

In an unpopular move, DoD recently suggested use of a re-opener or repricing clause in noncompetitive fixed-price contracts affected by pending or recent mergers or business combinations. ${ }^{\mathrm{xl}}$ DoD asserted that from the time a merger or acquisition is announced until the putative savings from the business combination are reflected in reduced overhead rates - fixed-price contracts are risky. Not surprisingly, industry opposition has been swift and fierce. ${ }^{\text {xli }}$ Much of the criticism focused upon the suggested "downward only" nature of the adjustments contemplated by the new rule. (Although, by historical analogy, public sentiment has never prompted Congress to mandate renegotiation of insufficiently profitable contracts.) Likewise, critics complained that the Government was introducing another avenue

Renegotiation, 10 LAW \& CONTEMP. PROBS. 276 (1944); Wadsworth Watts, Renegotiation and Federal Taxation, 10 LAW \& CONTEMP. PROBS. 341 (1944).

xl See e.g., DoD Proposes Reopener Clause In Response to GAO Study on Defense Industry Restructuring, 40 Gov'T CONTRACTOR II 551 (December 9, 1998); GAO Presses for Mandatory "Reopener" Clauses To Capture Restructuring Savings, 40 GOV' T CONTRACTOR II 347 (July 22, 1998) (discussing the GAO Report, Defense Industry: Restructuring Costs Paid, Savings Realized and Means to Ensure Benefits, NSIAD-99-22, December 1, 1998, and DoD's response); 63 Fed. Reg. 65727 (November 30, 1998).

xli See, e.g., Restructuring Costs: ABA Group Urges DoD to Scrap Proposed Rule on Use of Repricing Clause, 71 FED. CONT. REP. 219 (Feb. 15, 1999). 
permitting the adjustment of fixed-price contracts. This example proves telling, when juxtaposed against the historical example of renegotiation.

Both complaints, to a great extent, would be ameliorated by one key facet of renegotiation - the focus upon the individual firm's entire business base, rather than individual contracts. The Defense Department's claim -- based upon the forward pricing rates applied to an individual contract -- may seem to lack a sufficient nexus to the restructuring costs allowed on various contracts. Conversely, a more compelling case could be made that, to the extent that DoD subsidized - either directly or indirectly - defense firms' restructuring costs, it is reasonable for them to share in the long term savings associated with the firms' enhanced efficiency or productivity. Conversely, if other considerations, such as reduced business opportunities or competition from new entrants into the marketplace, resulted in restructured firms failing to recognize anticipated savings or efficiencies (on a firmwide basis), DoD's argument seems less compelling.

\section{An Analogy to Public Utilities and Telecommunications}

Recent developments in the field of public utility regulation offer another point of comparison. ${ }^{\text {xli }}$ Since the mid-1980's, regulation of electrical power and telecommunications services providers has

xlii See William E. Kovacic, Commitment in Regulation; Defense Contracting and Extensions to Price Caps, 3 J. REG. ECON. 219 (1991). See also the attempt to describe the defense industry as a public utility in CARL Michael MAYER, GOVERnMENT PROFIT POLICY 5-6 (Federal Publications course book October 1990). featured a shift from cost-based, rate of return oversight to "price cap" mechanisms that resemble fixed-price contracts between regulated firms and their regulators. Recognizing that utilities might realize politically insupportable profits under price cap systems, some jurisdictions have adopted "sharing" mechanisms, by which net returns are distributed between the utility and its ratepayers by a predetermined ratio. The sharing mechanism supplies an explicit, transparent means for treating "excessive" profits.

\section{A Modest Proposal}

In this brief paper, we do not advocate a sentimental revival of the Renegotiation Act. Rather we propose a study or examination of alternative methodologies for addressing the Government's obsession with the avoidance of paying excessive profits. At this preliminary stage, we suggest a three-tiered menu of options.

The first option would permit contractors to elect to remain within the current regime. They can accept the current system, warts and all. We do not doubt than many experienced contractors, and their counsel, would accept the existing pitfalls, disincentives, inefficiencies, and inconsistencies between contracts within business units, on the theory that the devil you know is better than one you don't. Obviously, where appropriate, they could and should seek commercial item exceptions, where appropriate.

The primary alternative would bring the Government as close as practicable to true commercial contracting, within a modified renegotiation regime agreed to by contract clause. The contractor would be exempt from TINA and CAS requirements, along with all price-related certifications and representations. Part of the contractual 
agreement would be to permit the DCAA to perform, on an annual basis, a limited audit -most likely in conjunction with the firm's independent auditors. Where a firm's cumulative profit exceeded the (yet unspecified) tolerable threshold, the firm would submit to renegotiation procedures. Such procedures would provide for some level of due process, for example, appeal rights under the Contract Disputes Act of 1978 (CDA). ${ }^{\text {xliii }}$ We would discourage the creation of a renegotiation board or similar entity until a need was established.

A middle ground might also ease the transition. The basic premise would follow the model of the Contractor System Purchasing Review (CPSR), ${ }^{\text {xliv }}$ which correlates oversight directly to compliance past performance. Basically, less contractor compliance prompts greater government review. Consistent compliance is rewarded by reduced reporting and oversight. Contractors with strong compliance records could apply for "renegotiation only" status, as described above. For contractors in whom the Government has less confidence, they could accept a voluntary "rehabilitation option," which included situation-specific elements of full TINA, CAS, or audit oversight. This

xliii $\quad 41$ U.S.C. $\S \S 601-613$.

xliv See generally, FAR Subpart 44.3. The CPSR is intended to "evaluate the efficiency and effectiveness with which the contractor spends Government funds and complies with Government policy when subcontracting[.]" FAR 44.301. The need for a CPSR is determined "based on, but not limited to, the past performance of the contractor[.]" FAR 44.302. The CPSR surveillance "plan should also provide for reviewing the effectiveness of the contractor's corrective actions taken as a result of previous Government recommendations." FAR 44.304. option would mandate strict time periods for upgraded status in the absence of demonstrated compliance deficiencies.

We expect individual contractors primarily would select the regime perceived to reduce their overall costs, thus optimizing their competitive standing. Not all contractors would choose the same path. Initially, some firms might choose to operate within the existing environment, a regime they understand or believe they have mastered. Such an approach would capitalize upon existing investments or sunk costs in CAS-complaint accounting systems or approved compliance programs, with customized training and controls.

Other firms might deduce that the ability to jettison their existing accounting and compliance burdens under the renegotiation regime could create a needed competitive edge, either through lower prices offered to the Government, or increased investment in facilities or research and development. Savvy firms may aspire to "earn" the least possible government oversight, advertising their positive compliance rating as firms today tout their quality standards. In any event, we sense that such an election would convey valuable information about individual firms and what image they seek to project to the Government and the public.

\section{Conclusions}

Modern procurement regulation relies upon a complex, costly system of controls to limit contractor earnings. Despite its own limitations, the use of an explicit, transparent renegotiation mechanism may improve efficiency by providing a less costly apparatus to satisfy the political (and, in some instances, economic) need to control supplier profits. A transparent renegotiation system could be one element of a regulatory scheme that presents 
suppliers with a menu of regulatory options. Such a regulatory scheme would allow contractors to select an approach that best corresponds to their own assessment of which contractual rules will minimize their costs.
Directly or indirectly, the Government would share in those savings. 